\title{
Bridging the Gap between Entrepreneurship Teaching and Economics
}

\section{Matthew McCaffrey}

Manchester Business School*

\begin{abstract}
Although entrepreneurship education is thriving, it often lacks a substantial foundation in economic theory and history, and therefore also an appreciation of the overarching social significance of entrepreneurship. This paper explores one way economics can enhance entrepreneurship teaching: by discussing the social and institutional basis of entrepreneurship, as well as its economic meaning and implications. To this end, I provide a list of economic readings that can be used in undergraduate entrepreneurship courses, along with brief narratives explaining some of the most important ideas these works communicate. The readings highlight key themes from the economics of enterprise, such as the importance of institutions, the roles of risk and uncertainty, the causes of profit, the process of entrepreneurial decision making, the sovereignty of consumers, and the effects of entrepreneurial competition.
\end{abstract}

\section{JEL Codes: A12, A22, L26}

Keywords: economics of entrepreneurship, economic education, entrepreneurship education, undergraduate education

\section{Introduction}

It is well known that entrepreneurship is one of the fastest-growing disciplines in management and the social sciences. Entrepreneurship courses are currently in high demand in business schools, which are increasing their research and teaching emphasis on entrepreneurial behavior in order to meet rising curiosity about new venture creation, small business management, and innovation (Kuratko 2005; Prior 2014). Unfortunately, there has been little interaction between entrepreneurship education and economics. While entrepreneurship programs do invoke economic concepts, few seek to seriously explain

\footnotetext{
* I thank William Kline, Geoffrey Lea, Kevin Currie-Knight, the participants at the 2014 Association of Private Enterprise Education Annual Meetings, and two anonymous referees for their helpful discussions and comments on the earlier drafts of this paper.
} 
the economic context in which entrepreneurship happens. This lack of communication can be attributed to the narrow focus of entrepreneurship studies; specifically, the type of entrepreneurship taught in business schools tends to emphasize creating new businesses rather than the broader economic and social implications of entrepreneurship (Klein 2008; National Survey of Entrepreneurship Education 2014). Nevertheless, studying new ventures leads naturally to an interest in the entrepreneur's significance for society generally. As I will show, entrepreneurship students have much to gain by incorporating such discussions into their studies.

This paper explains how entrepreneurship teaching can supplement typical coursework with a series of readings emphasizing the economic and social significance of enterprise. I argue that complementing undergraduate entrepreneurship courses with learning materials from economics encourages a fuller understanding of the social forces at work in business creation and innovation, while still allowing students space to pursue practical knowledge about how entrepreneurs launch new ventures. The paper is organized as follows: Section 2 explains the general benefits to students of incorporating economics into entrepreneurship education. Section 3 then outlines a series of readings instructors can use to deepen students' economic understanding of the entrepreneurial process, and describes a general narrative that the readings convey.

\section{The Economic Function of Entrepreneurship}

Market entrepreneurship takes place within the context of exchange relations, or what Ludwig von Mises called "catallactics." It is therefore a fundamentally economic activity. Given this fact, it is only natural that economics would be relevant for the study of entrepreneurship. However, it is difficult to understand the potential benefits to students of combining these topics without first recognizing the limitations of standard entrepreneurship courses. A significant problem in entrepreneurship education is that students learn many details of the process of new venture creation, but relatively little of the greater significance of entrepreneurial activity in society. In Klein's (2008) terminology, business courses tend to focus on "occupational entrepreneurship" rather than "functional entrepreneurship."

Entrepreneurship teaching does emphasize the importance of new and small businesses in the national economy, and usually nods 
in passing to concepts like Schumpeterian creative destruction. Yet, it includes hardly any analysis of the "big picture," or what is sometimes called "systems-level" thinking in entrepreneurship (McMullen and Shepherd 2006). Specifically, it lacks a discussion of the entrepreneur's economic function: the unique activity or process entrepreneurs engage in that reflects their special role in society. This function provides a rigorous social science foundation for studying entrepreneurship in practice; without it, students often learn to spot the new venture trees, while ignoring the economic forest.

This trend is changing as entrepreneurship teaching broadens its scope to include topics like social, cultural, and political entrepreneurship. These subfields help to explain the diverse forms entrepreneurial behavior takes, as well as its power to transform society in ways that extend beyond the marketplace. In addition, classroom entrepreneurship is placing new emphasis on different versions of traditional enterprise, such as green entrepreneurship, sustainable business, "conscious capitalism," and so on, all of which encourage students to consider goals besides strict profit maximization. However, these approaches often lack an appreciation of economics. Students tend to get confused in two ways, both of which can be overcome by exploring the entrepreneur's economic function. First, while teaching often discusses, for instance, the benefits of social enterprise for communities and economies, the benefits of "ordinary" market entrepreneurship are often left unexplained. This may be because conventional profit-seeking is insufficiently recognized as a driving force in social change, or it might simply be because it seems more mundane than trendier topics such as green technology, entrepreneurial social activism, or corporate social responsibility. Whatever the reason, vital economic ideas about institutions, uncertainty, profit and loss, and so on are neglected. A second and related problem is that these fashionable types of entrepreneurship are often viewed as substitutes for the usual activity of the market economy rather than complements, implying that "ordinary" entrepreneurship is economically or ethically suspect.

Fortunately, economic ideas can help clarify misunderstandings about the socially beneficial nature of market entrepreneurship. Specifically, an economic approach dispels confusion by providing a more complete framework within which to study entrepreneurial behavior. Instead of explaining new venture creation as such, economics helps students to understand its social context. What 
follows is a list of source materials intended not only to increase students' knowledge of economics, but also to encourage them to see that even small entrepreneurial acts are part of a much larger process of social change and progress that is brought about by, and mutually reinforces, the free choices of individuals.

\section{Recommended Readings on the Economic and Social Context of Entrepreneurship}

- William J. Baumol, "Entrepreneurship: Productive, Unproductive, and Destructive"

- Sun Tzu, The Art of War (selections)

- Bert F. Hoselitz, "The Early History of Entrepreneurial Theory"

- Deirdre N. McCloskey, Bourgeois Dignity: Why Economics Can't Explain the Modern World (selections)

- Joseph A. Schumpeter, Capitalism, Socialism, and Democracy (selections)

- Murray N. Rothbard, Man, Economy, \& State: Scholar's Edition (selections)

- Frank H. Knight, "Profit and Entrepreneurial Functions"

- Frank A. Fetter, Economic Principles and Problems (selections)

- Ludwig von Mises, "Profit and Loss"

- Ludwig von Mises, Human Action: Scholar's Edition (selections)

- F. A. Hayek, "Competition as a Discovery Procedure"

- Israel M. Kirzner, "The Perils of Regulation: A Market-Process Approach” (selections)

The complete list of readings includes both classic works in economics as well as newer research, and draws heavily on the writings of the Austrian school. To keep the discussion as accessible as possible to both students and instructors, I have focused on sources that are available online free of charge. Teachers can use the readings either to supplement current courses or to build new ones; however, while individual readings can be applied to specific topics in pre-existing courses, the complete list was initially conceived as the basis for a stand-alone course on the economic and social foundations of entrepreneurship. The above list is not at all exhaustive, and it reflects my personal tastes and classroom experiences. I hope my selections and their accompanying narratives inspire discussion among economists and entrepreneurship scholars alike. 


\section{An Economic Reading List for Entrepreneurship}

The readings discussed in this section can be divided into two main subjects: the institutional foundations of entrepreneurship and the process of entrepreneurial action. In each subsection, I discuss the texts in the order I consider to be most useful for students, though certain courses will naturally allow for variations in my arrangement.

\section{A. Entrepreneurs and Institutions}

In learning the foundations of entrepreneurship, students should understand first and foremost that it does not happen in a vacuum: the institutions of human society play a vital role in determining if and how entrepreneurship manifests. For instance, differences in growth between developed and developing nations, or between relatively free and unfree nations, can be largely explained by their different institutional arrangements, which play a large role in determining entrepreneurial behavior (Bjørnskov and Foss 2012). This fact should be explained in detail (preferably through a variety of sources) so that students understand how fragile the entrepreneurial society really is and the many threats it faces.

With this in mind, one way to understand the social significance of market entrepreneurship is to consider the world without it. The first reading is William Baumol's "Entrepreneurship: Productive, Unproductive, and Destructive" (1990). The essay explains how, throughout human history, the institutional environment critically influenced the channels into which entrepreneurial talent was directed. For example, many of the original "entrepreneurs" of the Middle Ages were innovative military leaders or engineers contracted to develop technology and tactics to grant a competitive edge to their political patrons. Innovations in the field of military science were a consequence of prevailing institutional arrangements, which rewarded martial ability more than market ability. This contrast highlights a recurring theme in these readings: not all forms of entrepreneurship are socially beneficial.

The second reading, Sun Tzu's The Art of War, illustrates Baumol's arguments. Sun Tzu's text has been extremely influential in the history of strategic thought, enjoys widespread popularity among business professionals, and has even been taught in entrepreneurship courses at Columbia University (Michaelson 1998). However, the text is not included here as a blueprint for entrepreneurship, but as a foil to it. The Art of War helps demonstrate that creative, innovative 
entrepreneurial thinking is ubiquitous in human life and culture, but is shaped and directed by institutions, as Baumol suggests. Especially important is the fact that the type of entrepreneurship that emerges in society is largely determined by the behaviors that government rewards and punishes. The Art of War is a product of its institutional milieu, which helps to explain why it is a text on military strategy, and not market entrepreneurship. It thus gives readers a glimpse of how entrepreneurial talent manifests when society rewards service to the state rather than service to consumers in the marketplace: warfare becomes a primary social value, and its scale and scope increase dramatically at the expense of the welfare of society at large, which must bear the physical and human cost of conflict. The Art of War thus eloquently reinforces the conclusion that not all forms of entrepreneurship are productive from the perspective of consumers, especially those not in a position to receive the patronage of government. Grasping this point leads students to a greater appreciation of the vital role entrepreneurial values play in steering society, which, as Deirdre McCloskey points out, are closely associated with the ability to flourish economically.

The Art of War is probably best read piecemeal alongside textbook materials. Its terse style means that it can be divided into small portions without losing any of its poetic elegance and that different ideas can be targeted to specific topics in the course. The value of The Art of $W$ ar lies in its concise treatment of strategic decision making, expressed in terms that are accessible to students of entrepreneurship. For instance, the main reason for the book's popularity in business circles is its emphasis on acquiring knowledge and creating opportunities, key themes in entrepreneurship teaching. It uses general but intuitive phrases to express the importance of gathering information, forming expectations, searching out opportunities, and acting decisively. In short, it summarizes how entrepreneurs can discover or create advantageous situations (McCaffrey 2014). Consider an illustration: Sun Tzu's principle that one should only fight when fully prepared and when victory is already assured applies to the competitive environment of the market and the need for entrepreneurs to make careful judgments before launching new ventures (Sun Tzu 1996, pp. 56-58). The Art of $W$ ar thus provides a different perspective on the themes of entrepreneurial decision-making and competition as stressed by Ludwig von Mises and other economists (discussed later). Likewise, Sun Tzu's commentary on the virtues and failings of generals-especially the 
importance of seeking self-knowledge and avoiding bias-can be used to discuss the personal traits of entrepreneurs (1996, pp. 5184). Similarly, his precepts on the importance of spying can facilitate discussions of ethics or intellectual property (1996, pp. 118-21). Using these and other examples, the ideas of the text can be spread throughout a course to emphasize particular points. ${ }^{1}$

Once the institutional conditions of entrepreneurship are examined, students are ready to understand how ideas about market entrepreneurship have evolved over time. It is especially important to explore how entrepreneurship came to be understood in its contemporary commercial sense, because the development of the concept is closely related to institutional factors. Bert Hoselitz's paper, "The Early History of Entrepreneurial Theory" (1960), discusses the origins of the term entrepreneur and the people to whom it was first applied. Hoselitz explains how entrepreneurship became a distinct concept during the creative revolution of the Renaissance. The term was often applied to military adventurers and government contractors rather than ordinary manufacturers and merchants. It was only with the advance of "nascent capitalism" that production plans were rationalized and a distinctly economic entrepreneurial function emerged in the marketplace. This development helped entrepreneurship to become broadly associated with commercial behavior and with more specific concepts such as creative planning, the supervision of production, and the bearing of uncertainty.

Changes in the common meaning of entrepreneurship reflected a much larger shift in human values and institutions that took place in the centuries prior to industrialization. This reading list highlights the importance of this transformation by examining the industrial revolution and the new entrepreneurial class it helped to create. It is important to cover this topic because, unfortunately, business students often learn little or nothing about economic history, how modern entrepreneurial economies came to exist, or what might threaten them. With that in mind, McCloskey's Bourgeois Dignity (2010) surveys an enormous range of explanations of the industrial revolution. McCloskey rejects one after another, finally settling on

\footnotetext{
${ }^{1}$ Using The Art of War serves two further purposes. First, it exposes students to a style of thinking about entrepreneurship that is radically different from conventional (i.e., Western) source materials, adding a much-needed degree of diversity to the reading list. Second, because the text was produced in a time, place, and culture quite different from the others discussed in this paper, it helps to reinforce the universality of entrepreneurship in the human experience.
} 
rhetoric as the ultimate cause. The expansive subject of the book means it covers a wide range of material relating to economic theory and history, much of it relevant to entrepreneurship in one way or another. However, reading the entire work could easily absorb a full semester, so it is necessary to focus on the most relevant sections. Fortunately, the book is divided into concise chapters, each covering a piece of McCloskey's overall argument. This means many of the discussions can be read independently.

The most important chapters for entrepreneurship are the ones explaining McCloskey's positive thesis regarding the emergence of the modern market economy. The relevant discussions take place mostly in chapters 1-3 (McCloskey 2010, pp. 1-30). ${ }^{2}$ Specifically, McCloskey argues that it was changing ideas about commerce and the merchant class - that is, the emergence of "bourgeois dignity" - that paved the way for a creative revolution in the marketplace. The pursuit of profit and business success through competition and innovation became not only socially acceptable, but admirable. Hence, a new entrepreneurial spirit was born that focused human energy on creativity, innovation, and challenging the unknown. Without these values, the modern market economy could not have developed, and entrepreneurial effort would still be largely directed toward political ends rather than producing value for consumers. From this, we can conclude that rhetoric about business plays an equal or even more important role in promoting commerce (or discouraging it!) as the ways in which people actually conduct business. The importance of this point for students of entrepreneurship cannot be overstated, because even in business schools, there is often a lack of rhetoric in support of commercial society and free exchange. Besides highlighting the importance of "bourgeois dignity" generally, other chapters make important supporting points about entrepreneurship. These can be assigned to specific student audiences, time and interest permitting. For instance, chapter 38, "The Cause Was Not Science," explains that increases in scientific knowledge in and of themselves are not responsible for human progress. Rather, both historically and in contemporary society, science improves human welfare once it is put to work by entrepreneurs trying to serve consumers.

\footnotetext{
2 McCloskey introduces the argument in the early chapters and returns to it in greater detail after critiquing alternative explanations. These later discussions occur mostly in chapters 39, 41, and 42. However, the opening chapters are more accessible to students new to the subject.
} 
After explaining the context of entrepreneurship and how it has changed historically_its past and present—students are ready to think about its long-term implications, its future. One advantage of economic discussion for students is that it allows the curriculum to integrate big-picture ideas about entrepreneurship and social change with narrower practical ideas about new venture creation. One example is Joseph Schumpeter's point that entrepreneurship transforms and renews economic activity through disruptive innovation. This idea is well-known, but is rarely studied in detail. Selections from Capitalism, Socialism, and Democracy, especially chapter 8, "The Process of Creative Destruction," will help put entrepreneurship in perspective by explaining the vital and defining role it plays in the market economy, as well as the evolutionary and revolutionary social change it brings about (Schumpeter 1942, pp. 81-86). Thinking of entrepreneurship as the market's driving force also gives us a glimpse of what happens without that force: stagnation, decline, and even large-scale state control of the economy. Capitalism, Socialism, and Democracy can also be used to make a rather anti-Schumpeterian point: that even small or seemingly mundane enterprises contribute vitally to creative destruction and economic progress.

\section{B. The Entrepreneurial Process}

The readings listed in section 2 are intentionally general, as they are designed to explain the context of entrepreneurship prior to discussions about business ideas and new venture creation. With these texts covered, the readings turn from studying the broader social role of entrepreneurs to a narrower discussion of entrepreneurial decision making and the competitive process it sets in motion. The following sources can be studied individually, or used to complement textbook entrepreneurship teaching.

To understand entrepreneurial behavior, we first need to consider the special environment in which it happens. Developing business ideas and launching new ventures takes time, and therefore entrepreneurs have to think seriously about the future. Planning for the future introduces the problem of risk, which is usually covered in entrepreneurship courses. However, economics can add important detail to students' understanding of risk and how it relates to entrepreneurship. Specifically, economics introduces the distinction between risk and uncertainty. These concepts are explained in a selection from Murray Rothbard's Man, Economy, and State titled 
"Risk, Uncertainty, and Insurance" (2004, pp. 552-55). ${ }^{3}$ Rothbard explains that risk is homogeneous, easily quantifiable, and can be pooled using insurance contracts. Uncertainty, however, is heterogeneous, difficult if not impossible to quantify, and must be overcome through superior judgment. Entrepreneurs play a special role in dealing with the uncertain future, and in doing so, they create value for consumers. One purpose of making the risk-uncertainty distinction is to show students just how challenging it is to become a successful entrepreneur, because the most important factors entrepreneurs need to predict-consumer preferences, for example_are fundamentally uncertain. Drawing attention to uncertainty, therefore, sets up the enormously complex economic problem that is solved by private enterprise and competition. Thus, once again, the text hints at a broader social implication of entrepreneurship that would otherwise be lost in a general discussion of risk-taking.

Perceiving the uncertainty inherent in commercial enterprise allows students to understand more clearly what entrepreneurs actually do. Frank Knight's essay "Profit and Entrepreneurial Functions" (1942) reiterates the importance of uncertainty and explains its implications for economic behavior. Specifically, Knight identifies three functions performed by entrepreneurs: innovation, adaptation, and uncertainty-bearing. Naturally, innovation and adaptation are prominent concepts in entrepreneurship education, and therefore provide a valuable case study in using economic ideas as a basis for understanding more recent advances. Entrepreneurs are business owners who take responsibility for the wise use of scarce resources, and entrepreneurship can therefore be thought of as a kind of problem-solving; the idea of uncertainty-bearing highlights the need for judgmental decision making by entrepreneurs in order to cope with unpredictable future events.

Frank Fetter notes the importance of uncertainty, judgment, and profit in a chapter of his Economic Principles and Problems titled "Various Shades of Profits" (Fetter 1915, pp. 358-68). ${ }^{4}$ This text clarifies the fundamental concept of entrepreneurial profit and the

\footnotetext{
3 Rothbard's discussion draws heavily on the ideas of Frank Knight (1921) and Ludwig von Mises (1949).

${ }^{4}$ Alternatively, Fetter (1936) provides a concise view of the entrepreneurial process, from the beginning of production through the pricing of the final consumer goods. Unfortunately, the volume in which this essay appears is quite rare, and therefore difficult for students and instructors to access.
} 
many factors that come together to produce profit and loss. In addition to risk and uncertainty, Fetter adds the notion of pure chance or luck, which can sometimes play a role in an enterprise's success. He also emphasizes the importance of advance knowledge, skill, and entrepreneurial foresight, which he suggests are subtler and more important determinants of profit. In particular, he argues that in the real world, what nonentrepreneurs see as pure chance is simply prescient entrepreneurial judgment. Fetter thus undermines common criticisms of the market economy that attribute commercial success and the distribution of wealth simply to good fortune. He also provides a valuable lesson for hopeful entrepreneurs: anyone launching a new venture should be aware of the vast scope for decision making implied in any business and should be prepared to accept responsibility for both wise and poor choices rather than attributing the results to luck.

Ludwig von Mises's essay "Profit and Loss" (1951) offers a basic and accessible explanation of entrepreneurship in the market economy. There are many useful points made in the essay, so I will mention only a few of the most important. In particular, Mises stresses the notion of consumer sovereignty and entrepreneurs' constant efforts toward the improvement of consumer welfare. Entrepreneurship students will already learn that to succeed in the marketplace, they must create value for consumers. Mises's essay builds on this idea by showing that in unregulated markets, entrepreneurs are constantly subject to the whims of consumers, and earning profit is impossible without serving other people. In fact, that is the great advantage of peaceful association and the market economy: they bring the divergent interests of society into harmony. This harmony manifests through the profit and loss system, which Mises emphasizes is the means by which consumers lead entrepreneurs to make the most valuable use of society's scarce resources. By explaining the benefits of entrepreneurship in this way, the essay demonstrates to students that even small businesses are part of a much larger market process that constantly improves human welfare.

Another advantage of "Profit and Loss" is its explanation of entrepreneurship as a kind of decision making. Although entrepreneurs perform many tasks within the firm, their defining characteristic is their control over the factors of production. This distinction is vital if students are to realize the unique function of entrepreneurship, which often appears murky when entrepreneurs 
play many roles within an organization. Mises further points out that entrepreneurship does not necessarily coincide with innovation or invention. Potential entrepreneurs should not forget that creating value often involves commonplace choices about how to best use resources, and is not always dramatic or especially innovative. Students will appreciate this observation because the entrepreneurship discipline tends to focus narrowly on the innovative and disruptive effects of entrepreneurship, as opposed to decision making in more "mundane" conditions. Given that most students will not be Schumpeterian creative destroyers, a measured approach goes a long way toward demystifying entrepreneurship and demonstrating that even ventures that do not transform the world can still be highly valuable.

Once the economic function of the entrepreneur is explained through the previous readings, it is natural to move to a discussion of competition between entrepreneurs. The section on competition from Mises's Human Action (1949, pp. 273-77) further develops the theme of consumer sovereignty, explaining that competition between entrepreneurs is not zero-sum, but benefits all consumers. The profit-and-loss system provides the means to express dissatisfaction, and therefore safeguards the interests of consumers and prevents exploitation-success, no matter how great, is always tenuous, a valuable lesson for hopeful entrepreneurs. Talking about the price system also sets up the discussion of intervention (and socialism) that appears at the end of the reading list.

Competition implies more than simply the pursuit of profit. Rivalry between entrepreneurs also performs the larger social function of discovering and spreading knowledge throughout the economy. This brings us to F. A. Hayek's essay "Competition as a Discovery Procedure" (2002). In it, he argues that competition is a process of the continual realization of opportunities to enhance human welfare. Discovering these opportunities in turn coordinates individuals' plans over time. This view contrasts sharply with the textbook economic view of competition as an equilibrium result where all gains from entrepreneurship and trade have been exhausted. It should not come as a surprise if students who are exposed only to this view of competition are unable to see how it relates to entrepreneurship. Yet as Hayek points out, the knowledge of the economic data required to reach equilibrium is not given to entrepreneurs; it is only revealed through their ceaseless efforts in the market, which never reaches equilibrium. Entrepreneurs actively 
produce and implement the data on which the market depends. In other words, they do not merely create new ventures: from moment to moment they create the market economy itself.

Finally, thinking about entrepreneurial competition in this light leads naturally to a discussion of economic policy. In his essay "The Perils of Regulation: A Market-Process Approach" (1985), Israel Kirzner analyzes the effects of government regulation on entrepreneurial behavior. I recommend assigning only the major parts of this paper, as Kirzner provides a large amount of background material to motivate the discussion, some of which is not relevant for entrepreneurship courses. In particular, the second half of the discussion of socialism, titled "Some Thoughts on the Socialist Calculation Literature," can be removed without reducing the argument's impact.

Kirzner argues that intervention in the market inevitably prevents entrepreneurs from discovering opportunities to increase consumer welfare. This occurs in some obvious ways, such as through price controls that prohibit entrepreneurs from engaging in mutually beneficial exchanges. However, distortions can also occur in ways that are more difficult to observe. For instance, a regulation such as a tax on profits discourages individuals from pursuing profitable ventures in the first place. Lacking the healthy incentive provided by profit, governments are unlikely to develop solutions to market imperfections, and are certainly less likely to discover them than entrepreneurs are. Another advantage of Kirzner's essay is that it surveys Mises and Hayek's views on economic calculation, and it draws parallels between intervention and socialism. This material, though somewhat more abstract than what entrepreneurship students are used to, offers further foundational insights from Mises and Hayek without having to devote too much of the reading list to their work. The above are just a few of the methods Kirzner uses to demonstrate the superiority of market results over intervention. His analysis is useful because it outlines several ways to think about how intervention hampers entrepreneurial efforts. Most entrepreneurship students will learn the basics of entry barriers, but Kirzner offers insight into the unseen effects of regulation as well. He thus reinforces the institutional arguments made by earlier readings, bringing the course full circle. Kirzner's policy analysis concludes the list of topics. 


\section{Conclusion}

Economics can enhance entrepreneurship teaching by providing insights into the social context in which it happens. In this paper, I suggested a list of readings that communicate to students core insights about the vital economic function of entrepreneurship in the economy, and in society more generally. However, this list is only one way economic ideas can be emphasized in entrepreneurship teaching. Much more could be done in the classroom to (a) incorporate cases from economic history and/or (b) contrast conflicting theories and historical accounts of entrepreneurship. In addition to its primary goal, then, this paper is also intended as the beginning of an academic discussion about how to incorporate economic ideas into current pedagogy in entrepreneurship and management. Although this is an extremely large task, I hope to have made a worthwhile beginning.

\section{References}

Baumol, William J. 1990. "Entrepreneurship: Productive, Unproductive, and Destructive." Journal of Political Economy, 98 (5): 893-921.

Bjørnskov, Christian, and Nicolai J. Foss. 2012. "How Institutions of Liberty Promote Entrepreneurship and Growth." In Economic Freedom of the World: 2012 Annual Report, James Gwartney, Robert Lawson, and Joshua Hall, 24770. Vancouver: Fraser Institute.

Fetter, Frank A. 1915. Economic Principles. New York: Century Co.

Fetter, Frank A. 1936. "Cost-Prices, Product-Prices, and Profits." In Economic Principles and Problems: Volume I, 3rd ed., ed. Walter E. Spahr. New York: Farrar and Rinehart.

Hayek, F. A. 2002. "Competition as a Discovery Procedure." Quarterly Journal of Austrian Economics, 5(3): 9-23.

Hoselitz, Bert F. 1960. "The Early History of Entrepreneurial Theory." In Essays in Economic Thought: Aristotle to Marshall. ed. Joseph J. Spengler and William R. Allen. Chicago: Rand McNally.

Kirzner, Israel M. 1985. "The Perils of Regulation: A Market-Process Approach.” In Discovery and the Capitalist Process, 119-49. Chicago: University of Chicago Press.

Klein, Peter G. 2008. "Opportunity Discovery, Entrepreneurial Action, and Economic Organization.” Strategic Entrepreneurship Journal, 2(3): 175-90.

Knight, Frank H. (1921) 1933. Risk, Uncertainty, and Profit. Series of Reprints of Scarce Works on Political Economy No. 16. London: London School of Economics and Political Science.

Knight, Frank H. 1942. "Profit and Entrepreneurial Functions." Journal of Economic History, 2(S1): 126-32.

Kuratko, Donald F. 2005. "The Emergence of Entrepreneurship Education: Development, Trends, and Challenges." Entrepreneurship Theory and Practice, 29(5): 577-98. 
McCaffrey, Matthew. 2014. "The Political Economy of the Art of War." Comparative Strategy, 33(4): 354-71.

McCloskey, Deirdre N. 2010. Bourgeois Dignity: Why Economics Can't Explain the Modern World. Chicago: University of Chicago Press.

McMullen, Jeffery S., and Dean A. Shepherd. 2006. "Entrepreneurial Action and the Role of Uncertainty in the Theory of the Entrepreneur." Academy of Management Review, 31(1): 132-52.

Michaelson, G. A. 1998. Sun Tzu: The Art of War for Managers. Alcoa: Pressmark International.

Mises, Ludwig von. (1949) 1998. Human Action: Scholar's Edition. Auburn, AL: Ludwig von Mises Institute.

Mises, Ludwig von. (1951) 2008. Profit and Loss. Auburn, AL: Ludwig von Mises Institute.

National Survey of Entrepreneurship Education. 2014. "An Overview of 20122014 Survey Data.” Washington: George Washington University Center for Entrepreneurial Excellence.

Prior, Anna. 2014. "What College Can Teach the Aspiring Entrepreneur." Wall Street Journal, November 3, D1-D2.

Rothbard, Murray N. 2004. Man, Economy, \& State: Scholar's Edition. Auburn, AL: Ludwig von Mises Institute.

Schumpeter, Joseph A. 1942. Capitalism, Socialism, and Democracy. New York: Harper and Brothers.

Sun Tzu. 1996. The Complete Art of War. Translated by Ralph D. Sawyer, with Meichün Lee Sawyer. Boulder: Westview Press. 